E. B. Напрасникова. Изучение почвенного покрова техногенной территории в условиях Восточной Сибири (экологический аспект)

УДК 631.46:504.05

DOI: $10.18101 / 2542-0623-2019-4-87-92$

\title{
ИЗУЧЕНИЕ ПОЧВЕННОГО ПОКРОВА ТЕХНОГЕННОЙ ТЕРРИТОРИИ В УСЛОВИЯХ ВОСТОЧНОЙ СИБИРИ (ЭКОЛОГИЧЕСКИЙ АСПЕКТ)
}

\section{Е. В. Напрасникова}

\section{(c) Напрасникова Елизавета Викторовна}

кандидат биологических наук, старший научный сотрудник, Институт географии имени В. Б. Сочавы СО РАН

Россия, 664033, г. Иркутск, ул. Улан-Баторская,1

E-mail:r.kodar@mail.ru

Получены новые экспериментальные данные при изучении почвенного покрова под действием аэротехногенного влияния алюминиевых заводов. Настоящий вопрос актуальный, своевременный и экологически значимый. Определены показатели щелочно-кислотных условий почвы, которые отражают тенденцию смещения $\mathrm{pH}$ в щелочную сторону. Степень биологической активности изучаемых почв позволила отнести их к среднеи высокоактивным. Установлена заметная (по шкале Чеддока) связь данной активности с щелочно-кислотными условиями $\left(\mathrm{R}^{2}=0,55-0,63\right)$ в городах Братск и Шелехов соответственно. В селитебной зоне г. Шелехов активность почв по сравнению с контролем высокая, что было доказано экспериментально в лабораторных условиях. Данный факт нельзя рассматривать как положительный, так как существенное увеличение биохимической активности почв (или) конкретно уреазной может привести к потере биогенного элемента - азота. Микробиологические анализы исследуемых почв показали, что количество аммонификаторов заметно снижается в промышленной зоне. Менее подвержены негативному воздействию эмиссий заводов, как в г. Шелехове, так и в Братске, бактерии, усваивающие минеральные источники азота, и актиномицеты.

Ключевые слова: г. Шелехов; г. Братск; почва; щелочно-кислотные условия; биологическая активность; микробоценозы.

\section{Для цитирования}

Напрасникова E. В. Изучение почвенного покрова техногенной территории в условиях Восточной Сибири (экологический аспект) // Природа Внутренней Азии. Nature of Inner Asia. 2019. № 4(13). C. 87-92. DOI: 10.18101/2542-0623-2019-4-87-92

\section{Введение}

В настоящее время специалисты разных научных направлений уделяют большое внимание изменению почвенного покрова городов, особенно индустриальных, где выражено влияние техногенеза [Бессолицина, 2009; Белозерцева, 2013].

Шелехов и Братск включены в приоритетный список городов с высоким уровнем загрязнения окружающей среды, так как являются крупнейшими производителями первичного алюминия [Госуд. доклад...,2013].

Кроме этого, важной причиной является то, что качество жизни городского населения во многом зависит от состояния почвенного покрова. Это обусловливает своевременность и актуальность проведенных исследований. 
Прогнозные оценки экологов сводятся к главному утверждению, что состояние почвенного покрова в промышленных городах и сопредельных территориях будет ухудшаться под воздействием техногенных факторов.

В связи с этим целью данной экспериментальной работы было определение экологического состояния почв, подверженных влиянию аэрогенных выбросов алюминиевых заводов. Одной из основных задач исследования явилось сравнение влияния приоритетных загрязнителей на почвенный покров разных городов. Отражены возможности использования интегральных почвенно-биотических показателей и их связь с экологическими факторами среды.

\section{Объекты и методы исследования}

Объектами детального исследования служили почвы городов Шелехов и Братск (Иркутская область). Город Шелехов находится в 20 км к юго-западу от областного центра - г. Иркутска, на юге Иркутско-Черемховской равнины. В зоне влияния Иркутского алюминиевого завода (ИркАЗа) преобладают антропогенно изменённые дерновые лесные почвы с маломощным гумусовым горизонтом [Белозерцева, 2013].

Содержание водорастворимой формы фтора значительно и может достигать 20 ПДК на расстоянии 0,5 км от завода в слое почвы 0-10 см. В атмосфере над ИркАЗом обнаружены бенз(а)пирен, формальдегид, хлорметан, диоксид азота, фтористый водород, твёрдые фториды, окислы кремния.

Город Братск расположен на северо-западе Иркутской области. В зоне влияния Братского алюминиевого завода (БрАЗа) преобладают антропогенно изменённые дерново-подзолистые и дерново-карбонатные почвы с небольшим по мощности гумусовым горизонтом. Содержание водорастворимого фтора в верхнем слое почв на расстоянии до 1 км от завода достигает 15 ПДК [Давыдова, 2007]. В атмосфере над БрАЗом обнаружены метилмеркаптан, бенз(а)пирен, диоксид серы, диоксид углерода [Госуд. доклад...,2013]

Биологическая активность почв (БАП) рассматривается как один из интегральных и информативных показателей её функциональных возможностей на текущий момент времени и контролируется экологическими факторами, особенно щелочнокислотными условиями. Анализы БАП выполнены экспресс-методом по Т. В. Аристовской, М. В. Чугуновой [1989]. Скорость выделяемого аммиака в процессе разложения модельного вещества - карбамида - считается уровнем активности почвы. Чем меньше количества часов, регистрирующих скорость реакции, тем больше уровень БАП.

Фитотоксичность почв установлена с помощью тест-культур высших растений классическим методом по Красильникову согласно ГОСТу РИСО [2009]. Отбор почвенных образцов, пробоподготовку и санитарно-микробиологическую оценку проводили по общепринятым методикам [Методы...,1991] и нормативам [Гигиенические нормативы, 2011].

\section{Результаты и их обсуждение}

Определение значений $\mathrm{pH}$ почвенного покрова (на глубине 0-10 см) показало смещение в область щелочных значений $(6,8-8,4$ ед.), которое варьировало в узких пределах, что свойствено большинству антропогенно изменённых почв индустри- 
E. B. Напрасникова. Изучение почвенного покрова техногенной территории в условиях Восточной Сибири (экологический аспект)

альных городов Восточной Сибири [Напрасникова, 2005; Белозерцева, 2013] и зарубежных стран [Lehmann A., Stahr K., 2007]. На графиках приведены результаты определения БАП функциональных зон городов и степень взаимосвязи с реакцией среды. Регрессионный анализ выявил между этими показателями достаточно тесную взаимосвязь. Коэффициент аппроксимации (рис. 1) достигает 0,63. По шкале Чеддока полученный результат характеризует качественную силу связи как заметную. При этом следует отметить величину БАП. Для почв г. Шелехова она колеблется от 2 до 8 часов и может считаться достаточно высокой.

Зависимость биологической активности почв г. Братска от реакции среды представлена на рис. 2. Количественная мера тесноты связи несколько меньше $(\mathrm{R}=0,55)$, но характеризуется (по шкале Чеддока) как заметная. При этом уровень активности почв г. Братска несколько выше и варьирует от 1 до 4 часов. Следует особо отметить, что на графиках (рис. 1,2 ) четко просматривается максимум показателей БАП в диапазоне рН от 7 до 8 единиц в обоих городах.

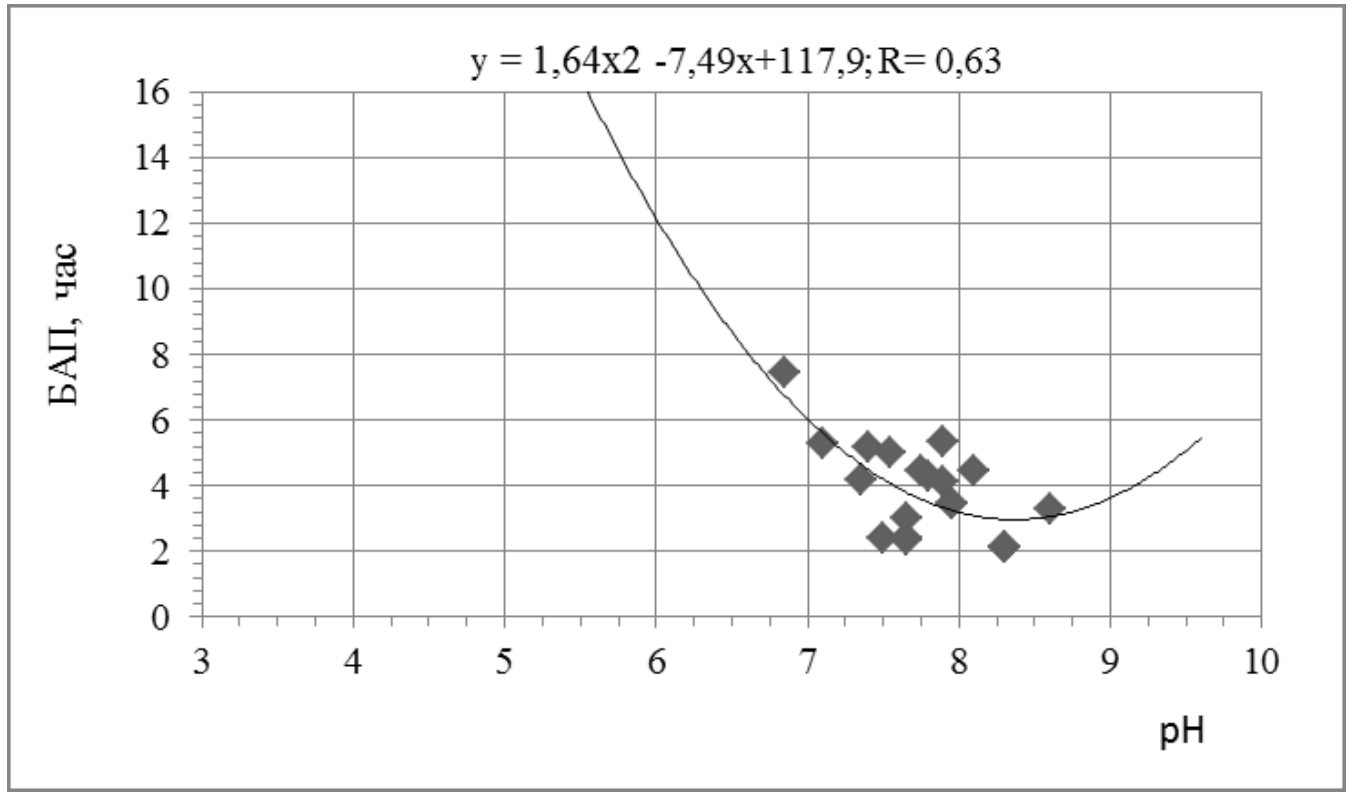

Puc. 1. Зависимость биологической активности почв г. Шелехова и сопредельных территорий от реакции среды

Данный факт не противоречит экологической сущности трансформации азотсодержащих органических веществ в почвах.

Должное внимание было уделено исследованиям почвенного покрова г. Шелехова в микробиологическом плане. Ожидаемые результаты подтвердились: в селитебных зонах и примыкающих к ним общественных центрах проявилось повышенное содержание бактерий - аммонификаторов. 


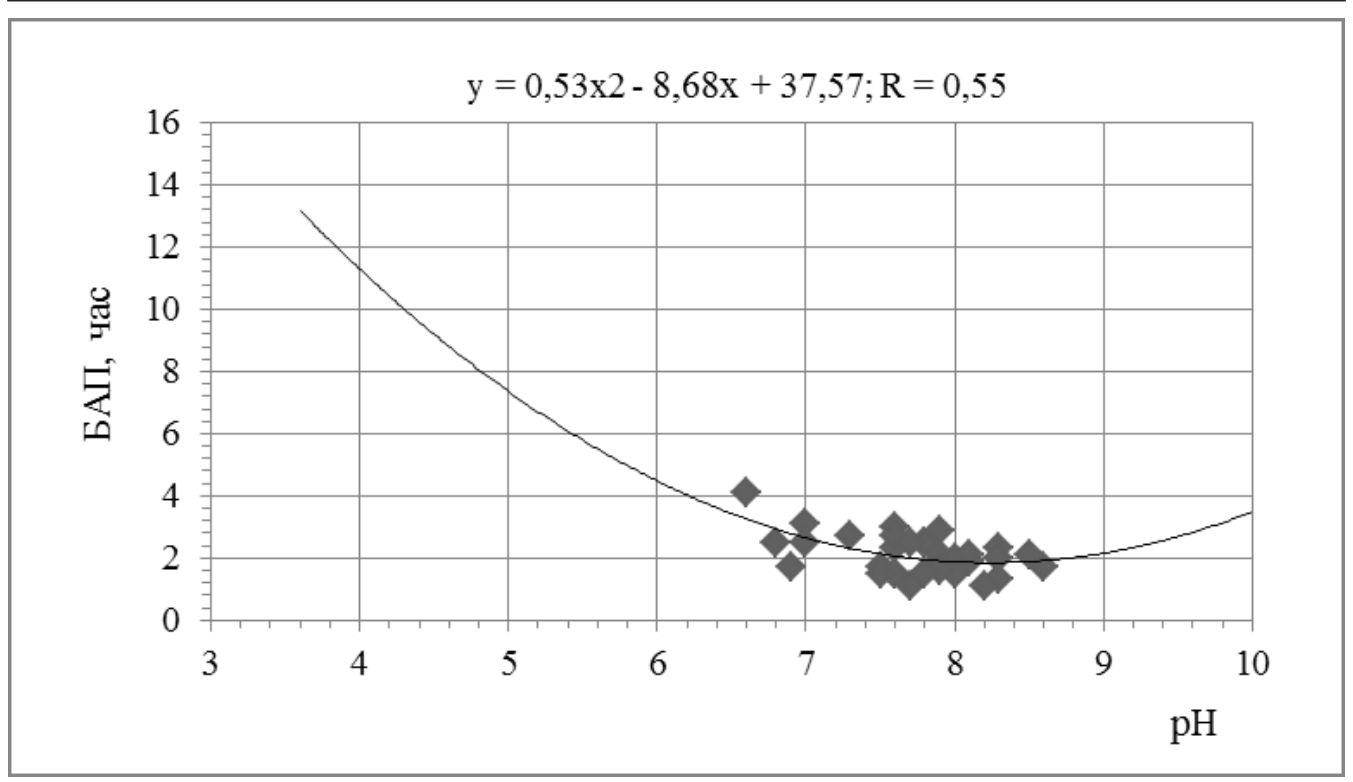

Puc. 2. Зависимость биологической активности почв г. Братска и сопредельных территорий от реакции среды

Их количество колебалось от 0,3 до 0,94 млн КОЕ/г почвы. Значительно меньше их в промышленной зоне (0,07 млн). В почвах селитебной зоны г. Братска численность данной группы высока (1,2 млн КОЕ/Г), но резко снижается в промышленной $(0,14$ млн КОЕ/г). Выявленные показатели в первом случае связываем с привносом хозяйственно-бытовой органики, в другом: ингибирующим воздействием аэротехногенных выбросов алюминиевой промышленности. Бактерии, усваивающие минеральные источники азота, и актиномицеты оказались менее подвержены негативному воздействию эмиссий заводов, как в Шелехове, так и в Братске, что было частично показано ранее [Макарова, Буковская, Напрасникова, 2017; Напрасникова, Истомина, 2018].

Кроме приоритетных загрязнителей в окружающую среду промышленных городов поступает множество экотоксичных веществ. При этом диагностировать такие вещества не всегда представляется возможным. В связи с этим методом биотестирования (фитотоксичности) можно получить объективную информацию о токсичности почвы в реальном времени.

Результаты определений фитотоксичности в лабораторных условиях позволили выявить преобладающее количество почв, ингибирующих прорастание семян высших растений не более чем на $10-25 \%$. Это свидетельствует о том, что изучаемые почвы не достигают порога токсичности. Их можно считать вполне сохранными. Однако в других случаях (промзона БрАЗа, основные транспортные магистрали, автозаправочные станции (АЗС)) зафиксировано угнетение семян на 30-35\%. При этом следует отметить, что почвенные образцы в промзонах и АЗС ИркАЗа и БрАЗа под растительностью показали степень угнетения прорастания испытуемых семян гораздо меньше, чем в почвах без растительности. 
E. B. Напрасникова. Изучение почвенного покрова техногенной территории в условиях Восточной Сибири (экологический аспект)

\section{Заключение}

В работе показано состояние почвенного покрова двух индустриальных городов Восточной Сибири под воздействием выбросов алюминиевой промышленности в экологическом аспекте. По интегральным показателям - биологическая активность, фитотоксичность и $\mathrm{pH}$ почв - выявлено, что и высокие, и низкие значения $\mathrm{pH}$ и БАП свидетельствуют о тенденции нарушения механизмов регуляции метаболизма органических веществ. Полученные результаты можно считать прогностическими.

Проведенные исследования рассматриваем как новые экологические знания о состоянии почв в условиях техногенеза. Кроме этого, исследования, проведенные в двух промышленных городах, имеют практическую направленность. Они могут быть полезны при решении и реализации вопросов благоустройства городов Восточной Сибири. Анализ совокупности всех экспериментальных данных позволяет считать, что на данный момент времени почвы исследуемых городов не относятся к деградированным, но нуждаются в экологическом мониторинге.

\section{Литература}

1. Аристовская Т.В., Чугунова М.В. Экспресс-метод определения биологической активности почв // Почвоведение. 1989. № 11. С. 142-147.

2. Бессолицина Е. П. Экологический контроль за изменением биотических компонентов степных геосистем в условиях техногенной геохимической аномалии // Аридные экосистемы. 2009. T. 15, № 2(38). С. 63-73.

3. Белозерцева И.А. Мониторинг загрязнения окружающей среды в зоне воздействия ИркАЗа // Вода: химия и экология. 2013. № 10. С. 33-38.

4. Гигиенические нормативы / отв. ред. Г. Г. Онищенко. СПб.: Профессионал, 2011. С. 118.

5. ГОСТ РИСО 22030-2009. Качество почвы. Биологические методы. Хроническая фитотоксичность в отношении высших растений. М.: Изд-во стандартов, 2009. 20 с.

6. Государственный доклад о состоянии и об охране окружающей среды Иркутской области в 2012 году. Иркутск: Изд-во Института географии им. В. Б. Сочавы, 2013. 337 с.

7. Давыдова Н. Д. Техногенные потоки и дифференциация веществ в геосистемах // Географические исследования в Сибири. Новосибирск: Наука, 2007. С. 261-276.

8. Макарова А.П., Буковская Н.Е., Напрасникова Е. В. Воздействие аэротехногенных выбросов алюминиевых производств в Иркутской области на почвенную микробиоту // Известия Иркутского государственного университета. Сер. Биология. Экология. 2017. Т. 19. С. 57-62.

9. Методы почвенной микробиологии и биохимии / отв. ред. Д. Г. Звягинцев. М.: Изд-во МГУ, $1991.303 \mathrm{c}$.

10. Напрасникова Е. В. Уреазная активность и $\mathrm{pH}$ как показатели экологического состояния почв городов Восточной Сибири // Почвоведение. 2005. № 11. С. 1345-1352.

11. Напрасникова Е. В., Истомина Е. А. Исследование и картографирование экологобиохимического состояния почв города Братска // Геодезия и картография. 2018. Т. 79, № 5. C. 20-26. DOI: 10.22389/0016-7126-2018-935-05-00-00.

12. Lehmann A., Stahr K. Nature and Significance of Anthropogenic Urban Soils // J. of Soils \& Sediments. 2007. Vol. 7, № 4. P. 247-260. 


\title{
STUDY OF THE SOIL COVER OF TECHNOGENIC TERRITORY IN EASTERN SIBERIA (ENVIRONMENTAL ASPECT)
}

\author{
E. V. Naprasnikova
}

\section{Elizaveta V. Naprasnikova}

Cand. Sci. (Biol.), Senior Researcher,

Sochava Institute of Geography SB RAS

1 Ulan-Batorskaya St., Irkutsk 664003, Russia

E-mail: r.kodar@mail.ru

The article presents new experimental data on the aerotechnogenic influence of aluminum plants on soil covering. Today this problem is relevant and environmentally significant. We have determined the indicators of alkaline-acid soil conditions, and revealed a tendency for $\mathrm{pH}$ shift to alkalinity. The degree of biotic soil activity allowed us to refer them to medium and highly active. There is a noticeable correlation (on the Chaddock scale) between this activity and alkaline-acid conditions in Bratsk and Shelekhov respectively ( $\mathrm{R} 2=0.55-0.63)$.

Soil activity in the settlement zone of Shelekhov is higher than in the control, it was experimentally proved in laboratory conditions. A significant increase in the biochemical activity of soils (particularly urease activity), can lead to the loss of a biogenic element nitrogen. Microbiological analyzes of the studied soils showed that the amount of ammonifiers decreases markedly in the industrial zone. Bacteria that absorb mineral sources of nitrogen and actinomycetes are less susceptible to the negative effects of plant emissions, both in Shelekhov and Bratsk.

Keywords: Shelekhov; Bratsk; soil; alkaline-acid conditions; biotic soil activity; microbiocenosis. 